\title{
Succession of cable bacteria and electric currents in marine sediment
}

\author{
Regina Schauer ${ }^{1,2}$, Nils Risgaard-Petersen ${ }^{1,2}$, Kasper U Kjeldsen ${ }^{1,2}$, Jesper J Tataru Bjerg ${ }^{2}$, \\ Bo B Jørgensen ${ }^{1,2}$, Andreas Schramm ${ }^{1,2}$ and Lars Peter Nielsen ${ }^{1,2}$ \\ ${ }^{1}$ Center for Geomicrobiology, Department of Bioscience, Aarhus University, Aarhus, Denmark and \\ ${ }^{2}$ Section for Microbiology, Department of Bioscience, Aarhus University, Aarhus, Denmark
}

\begin{abstract}
Filamentous Desulfobulbaceae have been reported to conduct electrons over centimetre-long distances, thereby coupling oxygen reduction at the surface of marine sediment to sulphide oxidation in sub-surface layers. To understand how these 'cable bacteria' establish and sustain electric conductivity, we followed a population for 53 days after exposing sulphidic sediment with initially no detectable filaments to oxygen. After 10 days, cable bacteria and electric currents were established throughout the top $15 \mathrm{~mm}$ of the sediment, and after 21 days the filament density peaked with a total length of $2 \mathrm{~km} \mathrm{~cm}^{-2}$. Cells elongated and divided at all depths with doubling times over the first 10 days of $<20 \mathrm{~h}$. Active, oriented movement must have occurred to explain the separation of $\mathrm{O}_{2}$ and $\mathrm{H}_{2} \mathrm{~S}$ by $15 \mathrm{~mm}$. Filament diameters varied from $0.4-1.7 \mu \mathrm{m}$, with a general increase over time and depth, and yet they shared 16S rRNA sequence identity of $>98 \%$. Comparison of the increase in biovolume and electric current density suggested high cellular growth efficiency. While the vertical expansion of filaments continued over time and reached $30 \mathrm{~mm}$, the electric current density and biomass declined after 13 and 21 days, respectively. This might reflect a breakdown of short filaments as their solid sulphide sources became depleted in the top layers of the anoxic zone. In conclusion, cable bacteria combine rapid and efficient growth with oriented movement to establish and exploit the spatially separated half-reactions of sulphide oxidation and oxygen consumption. The ISME Journal (2014) 8, 1314-1322; doi:10.1038/ismej.2013.239; published online 23 January 2014 Subject Category: Microbial ecology and functional diversity of natural habitats

Keywords: cable bacteria; Desulfobulbaceae; electric currents; filament; growth; marine sediment
\end{abstract}

\section{Introduction}

Electric currents can couple oxygen reduction at the surface of marine sediment with sulphide oxidation located more than a centimetre deeper down (Nielsen et al., 2010; Risgaard-Petersen et al., 2012). So far the electric currents have not been measured directly. The evidence for the transport of electrons between the spatially separated redox half-reactions includes the formation of a centimetre-wide suboxic zone in the absence of advection or bioturbation, and a distinct $\mathrm{pH}$ peak in the oxic zone due to proton consumption during cathodic oxygen consumption (COC) (that is, $\mathrm{O}_{2}+4 \mathrm{e}^{-}+4 \mathrm{H}^{+} \rightarrow 2 \mathrm{H}_{2} \mathrm{O}$ ).

Hitherto unknown filamentous, multicellular bacteria of the deltaproteobacterial family Desulfobulbaceae have been identified to mediate this transport of electrons from sulphide to oxygen (Pfeffer et al., 2012). Along their entire length, these

Correspondence: LP Nielsen, Center for Geomicrobiology/ Microbiology, Department of Bioscience, University of Aarhus, Ny Munkegade 114, DK-8000 Aarhus, Denmark. Email: lars.peter.nielsen@biology.au.dk

Received 18 July 2013; revised 12 November 2013; accepted 4 December 2013; published online 23 January 2014 filaments have either 15 or 17 uniform ridges formed by strings inside a periplasmic space that is continuous between the individual cells. The strings are proposed to function as electric wires with the surrounding cytoplasmic and periplasmic membranes serving as insulation (Pfeffer et al., 2012).

Mass balance studies in sediment with electric currents have shown that hydrogen sulphide diffusing from below can be a minor sulphide source compared with the dissolution of iron sulphide and sulphate reduction within the suboxic zone, where the free sulphide concentration stays below the detection limit of $\sim 1 \mu \mathrm{M}$ (Risgaard-Petersen et al., 2012). For 'cable bacteria' this means that all cells in the anoxic zone may oxidize sulphide while all cells in the oxic zone may reduce oxygen, while presumably no cell does both oxidation and reduction. The redox reactions are therefore shared among different cells instead of having the two half-reactions in the same cell.

This scenario raises intriguing questions about physiology, growth and spreading of cable bacteria. To address such questions, we incubated sulphidic marine sediment with overlying oxic water and followed the succession of cable bacteria and electric currents for 53 days with detailed vertical 
resolution. The results allowed analysis of growth rates, growth efficiency, dominance, morphological changes, diversity and dispersal of filaments.

\section{Materials and methods}

Sampling and treatment

Sediment was collected in November 2011 with a box corer from Station M5 $\left(56^{\circ} 06^{\prime} 20^{\prime \prime} \mathrm{N}, 10^{\circ} 27^{\prime} 48^{\prime \prime} \mathrm{E}\right)$ in Aarhus Bay, Denmark, at $30 \mathrm{~m}$ water depth $\left(11^{\circ} \mathrm{C}\right.$, $27.5 \%$ ). The upper $15 \mathrm{~cm}$ of the sediment was discarded and the underlying sulphidic sediment was sieved, homogenized and distributed in glass liner cores as described before (Nielsen et al., 2010), except that instead of working under $\mathrm{N}_{2}$ atmosphere, the sediment was handled swiftly and with minimal exposure to air. The cores (height, $70 \mathrm{~mm}$; inner diameter, $45 \mathrm{~mm}$ ) were incubated in the dark, submerged in a seawater aquarium $\left(15.2^{\circ} \mathrm{C}\right.$; $25 \%$ Red Sea Salts (Red Sea Fish Pham LTD, Eilat, Israel)) gently aerated with compressed air. The total incubation time was 53 days, with microprofiles recorded at seven time points (day 0, 6, 10, 13, 21, 40 and 53). At five time points (day 0, 10, 13, 21 and 53), three cores were killed and subsampled for DNA/RNA extractions and for fluorescence in situ hybridization (FISH). Two additional cores were sampled at the end of the incubation for analysis of dissolved inorganic carbon concentration in the porewater of the oxic zone (upper $3 \mathrm{~mm}$ ). Three cores were set up as negative controls with a horizontal polycarbonate filter (pore size $0.22 \mu \mathrm{m}$ ) placed at $2 \mathrm{~mm}$ depth to prevent proliferation of cable bacteria (Pfeffer et al., 2012), with insignificant impacts on diffusional transport (Sayre, 1926). At three time points (day 0, 10 and 13), one control core was profiled, killed and subsampled for dissolved inorganic carbon and FISH analysis.

\section{Microsensor profiling and flux estimations}

Microprofiles were recorded with $\mathrm{H}_{2} \mathrm{~S}$, $\mathrm{pH}$ and $\mathrm{O}_{2}$ microsensors (Unisense, Aarhus, Denmark) as previously described (Revsbech and Jorgensen, 1986; Revsbech, 1989; Jeroschewski et al., 1996). One set of profiles was recorded in each of the three incubated cores as well as in the control core per time point. The total hydrogen sulphide in the sulphidic zone $\sum \mathrm{H}_{2} \mathrm{~S}, \quad\left(\sum \mathrm{H}_{2} \mathrm{~S}=\left[\mathrm{H}_{2} \mathrm{~S}\right]+\left[\mathrm{HS}^{-}\right]+\left[\mathrm{S}^{2-}\right]\right)$ was calculated from parallel $\mathrm{H}_{2} \mathrm{~S}$ and $\mathrm{pH}$ profiles (Jeroschewski et al., 1996). [HS ${ }^{-}$] was calculated as the difference between $\sum \mathrm{H}_{2} \mathrm{~S}$ and the measured concentration of $\mathrm{H}_{2} \mathrm{~S}$, as $\left[\mathrm{S}^{2-}\right]$ is negligible at the $\mathrm{pH}$ range observed in the sulphidic zones $(<8)$.

Minimum electric current density equivalent to minimum COC was obtained from proton/electron/ oxygen mass balance calculations (Nielsen et al., 2010). Without sulphide in reach of the oxic zone it could be assumed that for each $\mathrm{O}_{2}$ molecule reduced through COC, four protons are consumed (that is, $\mathrm{O}_{2}+4 \mathrm{e}^{-}+4 \mathrm{H}^{+} \rightarrow 2 \mathrm{H}_{2} \mathrm{O}$ ) and that all other $\mathrm{O}_{2}$ consumption processes generate minimum one proton per $\mathrm{O}_{2}$ molecule reduced at $\mathrm{pH}>8$ (Soetaert et al., 2007). On day 1 when oxygen and sulphide reacted directly at the surface, the COC calculation was adjusted to take into account the possibility of sulphide oxidation to elemental sulphur, $\mathrm{S}^{0}$, which would consume up to one proton:

$$
\begin{gathered}
\mathrm{H}_{2} \mathrm{~S}+0.5 \mathrm{O}_{2} \rightarrow \mathrm{S}^{0}+\mathrm{H}_{2} \mathrm{O} \\
\mathrm{H}^{+}+\mathrm{HS}^{-}+0.5 \mathrm{O}_{2} \rightarrow \mathrm{S}^{0}+\mathrm{H}_{2} \mathrm{O}
\end{gathered}
$$

Incorporating this stoichiometry into the model of Nielsen et al. (2010), gives the following relationship between COC, the diffusive $\mathrm{O}_{2}$ uptake (DOU), the diffusive flux of $\mathrm{HS}^{-}$and $\sum \mathrm{H}_{2} \mathrm{~S}$ into the oxic zone and the rate of aerobic net proton consumption $\left(\mathrm{UH}^{+}\right)$:

$\mathrm{UH}^{+}=4 \mathrm{COC}-\left(\mathrm{DOU}-\mathrm{COC}-0.5 \times\right.$ flux $\left.\sum \mathrm{H}_{2} \mathrm{~S}\right)+$ flux HS

which is rearranged to

$\mathrm{COC}=\left(\mathrm{UH}^{+}+\mathrm{DOU}-0.5 \times\right.$ flux $\sum \mathrm{H}_{2} \mathrm{~S}-$ flux $\left.\mathrm{HS}^{-}\right) / 5$

DOU was determined from numerical modelling of the measured $\mathrm{O}_{2}$ profiles (Berg et al., 1998). The fluxes of $\mathrm{HS}^{-}$and $\sum \mathrm{H}_{2} \mathrm{~S}$ were calculated from the porewater profiles of $\mathrm{H}_{2} \mathrm{~S}$ and $\mathrm{HS}^{-}$using Fick's first law. The diffusion coefficients used in these calculations were calculated according to Ullman and Aller (1982) from the sediment porosity (determined gravimetrically on $3-\mathrm{mm}$ or $6-\mathrm{mm}$ sediment slices) and the diffusion coefficient of the respective species at infinite dilution (obtained from Boudreau, 1996).

Minimum estimates of aerobic net proton consumption $\left(\mathrm{UH}^{+}\right)$were calculated from concentration profiles of $\mathrm{H}_{2} \mathrm{CO}_{3}$, and $\mathrm{HCO}_{3}^{-}$in the oxic zone, assuming that the carbonate system is the only important $\mathrm{pH}$ buffer in the sediment (Nielsen et al., 2010). The concentration of $\mathrm{H}_{2} \mathrm{CO}_{3}$ and $\mathrm{HCO}_{3}^{-}$was calculated from the measured $\mathrm{pH}$ profiles and the dissolved inorganic carbon concentration in the oxic zone $(3.6 \pm 0.06 \mathrm{~mm})$ using carbonic acid dissociation constants given by Stumm and Morgan (1981). The concentration of dissolved inorganic carbon in the sediment porewater of the oxic zone was measured as $\mathrm{CO}_{2}$ after acidification of porewater extracts on a gas chromatograph equipped with a thermal conductivity detector (ML GC 82, Mikrolab, Aarhus, Denmark).

\section{Fluorescence in situ hybridization}

Sediment cores were sliced in layers of $1.5 \mathrm{~mm}$ (oxic zone), $3 \mathrm{~mm}$ (suboxic zone) and $6 \mathrm{~mm}$ (sulphidic zone) using a plunger on a threaded rod being rotated stepwise upwards through a fixed nut. The protruding sediment was cut off by a scalpel, transferred to a Petri dish and subsampled by sterile $2 \mathrm{ml}$ syringes. 
From each layer, $0.5 \mathrm{ml}$ sediment was preserved in $96 \%$ ethanol and stored at $-20^{\circ} \mathrm{C}$. Subsamples of $100 \mu \mathrm{l}$ were transferred to $500 \mu \mathrm{l}$ of a 1:1 mixture of phosphate-buffered saline and ethanol, and $10 \mu \mathrm{l}$ of this mixture was filtered through polycarbonate membrane filters (type GTTP, pore size $0.2 \mu \mathrm{m}$, Millipore, Billerica, MA, USA). FISH was performed according to previously published protocols (Pernthaler et al., 2001). Probe hybridization parameters are listed in Supplementary Table S1. Cable bacteria were detected with probe DSB706 (Manz et al., 1992), targeting most Desulfobulbaceae and Thermodesulforhabdus. Instead of single cell counts, filament length was used to quantify cable bacteria density over time. Length and diameter of the cable bacteria were determined by microscope digital photography using imaging software (AxioVision, Carl Zeiss, Göttingen, Germany). The density of cable bacteria was recorded per grid mask $(120 \times 120 \mu \mathrm{m})$ until a coefficient of variation $<2 \%$ was reached or 2000 grid masks had been inspected. For each time point, the total density of cable bacteria results from depth integration per $\mathrm{cm}^{2}$. Total cell counts were performed after staining with $4^{\prime}, 6$-diamidino-2-phenylindole $\left(1 \mathrm{mg} \mathrm{ml}^{-1}\right)$. The minimum limits of quantification via FISH for single cells were $1.5 \times 10^{6} \mathrm{cells} \mathrm{cm}^{-3}$, taken as the FISH count with the negative control probe NON338; a minimum of 1000 4',6-diamidino-2-phenylindole-stained cells was evaluated for this count. Owing to the unmistakable morphology of filaments $>3$ cells long, the FISH detection limit for cable bacteria was lower than for single cells, and was calculated to be $1 \times 10^{4}$ filaments $\mathrm{cm}^{-3}$ (or about $10 \mathrm{~cm}$ filament $\mathrm{cm}^{-3}$ ) from the total number (2000) of grid masks counted (corresponding to $<1$ filament in $0.1 \mu \mathrm{l}$ of sediment).

16S rRNA sequence-based analysis of cable bacteria Clumps of filaments were transferred to a microscope slide. Under a dissection microscope, single filaments were picked with a fine glass hook and washed in $10 \mu \mathrm{l}$ droplets of $1 \times$ TAE ( $40 \mathrm{~mm}$ Tris-acetate, $1 \mathrm{~mm}$ EDTA, pH 8.0). After measuring the diameter of each single filament by phase contrast microscopy at $\times 1000$ magnification, the filaments were transferred with a glass hook into a sterile PCR-tube by breaking off the tip of the glass hook. Cells were lysed by three freeze/thaw cycles. In addition, RNA was extracted from $0.5 \mathrm{~g}$ frozen sediment of pooled layers $(1.5-6 \mathrm{~mm}$ depth) at t10 and t53 using the RNA PowerSoil Total RNA Isolation Kit (MO BIO Laboratories, Carlsbad, CA, USA). Samples for RNA extractions were taken from the same core as used for FISH analysis. As RNA extractions were used to retrieve cable bacteria-related sequences for phylogenetic analysis, RNA extracts were directly used for reverse transcription-PCR without further DNase treatment. Reverse transcription-PCR was performed using the primer pair 341F/DSBB + 1297R (Muyzer et al., 1993;
Kjeldsen et al., 2007) (sediment samples, single filaments-J) or 341F/907R (Lane 1991; Teske et al., 1996) (single filaments-LK). Reverse transcriptionPCR was performed according to the manufacturer's instructions of the OneStep RT-PCR kit (Qiagen, Copenhagen, Denmark). After $30 \mathrm{~min}$ at $50{ }^{\circ} \mathrm{C}$ for reverse transcription and $15 \mathrm{~min}$ at $95^{\circ} \mathrm{C}$ for PCR activation, PCR was performed with 30 cycles, consisting of $45 \mathrm{~s}$ at $94{ }^{\circ} \mathrm{C}, 45 \mathrm{~s}$ at $57^{\circ} \mathrm{C}$ and $45 \mathrm{~s}$ at $72{ }^{\circ} \mathrm{C}$. The amplicons were purified using the Agencourt AMPure XP system (Beckmann Coulter $\mathrm{GmbH}$, Krefeld, Germany) and cloned using vector pCR4-TOPO with the TOPO TA Cloning Kit (Invitrogen $\mathrm{GmbH}$, Karlsruhe, Germany) for sediment samples or the pGEM-T Easy Vector Kit (Promega, Madison, WI, USA) for single filament samples. Clones with a correct insert size were commercially sequenced (GATC, Constance, Germany) using the vector primers M13F and M13R.

Sequence quality was manually checked, and forward and reverse reads were assembled using Sequencher (Gene Code, Ann Arbor, MI, USA). Sequences were aligned using the SILVA Incremental Aligner (SINA, v1.2.11; Pruesse et al., 2012) and added to the SILVA database 111 (Pruesse et al., 2007) using the ARB software package (v5.2; Ludwig et al., 2004). Subsequently, alignments were manually refined. The ARB software package was used to generate phylogenetic trees applying the maximum likelihood algorithm (RaxML) with a 50\% positional conservation filter and with 1000 bootstrap replicates. Sequences obtained in this study were deposited at EMBL under the accession numbers HG004404-HG004415 (single cable bacteria) and HG004416-HG004420 (bulk sediment rRNA).

\section{Results}

Biogeochemistry and electric currents

At the start of incubation, $\sum \mathrm{H}_{2} \mathrm{~S}$ was detectable right up to the oxic-anoxic interface at $1 \mathrm{~mm}$ below the sediment surface (Figure 1a). On day 10, however, profiling showed a clear separation of $\mathrm{O}_{2}$ and $\sum \mathrm{H}_{2} \mathrm{~S}$ resulting in a suboxic zone of $2-8 \mathrm{~mm}$ depth. The suboxic zone continued to develop over time and after 53 days the suboxic zone reached a maximum depth of $20 \mathrm{~mm}$. At day 10, a pH peak was detected in the oxic zone and it persisted until the end of the incubation (Figure 1b). After 10 days of incubation, calculations showed that the COC accounted for at least $81 \%$ of the total oxygen consumption of the sediments, thus representing a current density of $75 \mathrm{~mA} \mathrm{~m}^{-2}$. A maximum COC of $23 \mathrm{mmol} \mathrm{O}_{2} \mathrm{~m}^{-2}$ per day representing $61 \%$ of the total oxygen consumption of the sediment was reached at day 13 (Figure 2). After this peak, the COC continuously decreased to only $4 \mathrm{mmol} \mathrm{O}_{2} \mathrm{~m}^{-2}$ per day at day 53. The $\sum \mathrm{H}_{2} \mathrm{~S}$ flux from below calculated from the steepest, lower gradient of $\sum \mathrm{H}_{2} \mathrm{~S}$ (Figure 1a) contributed less than $30 \%$ to the 

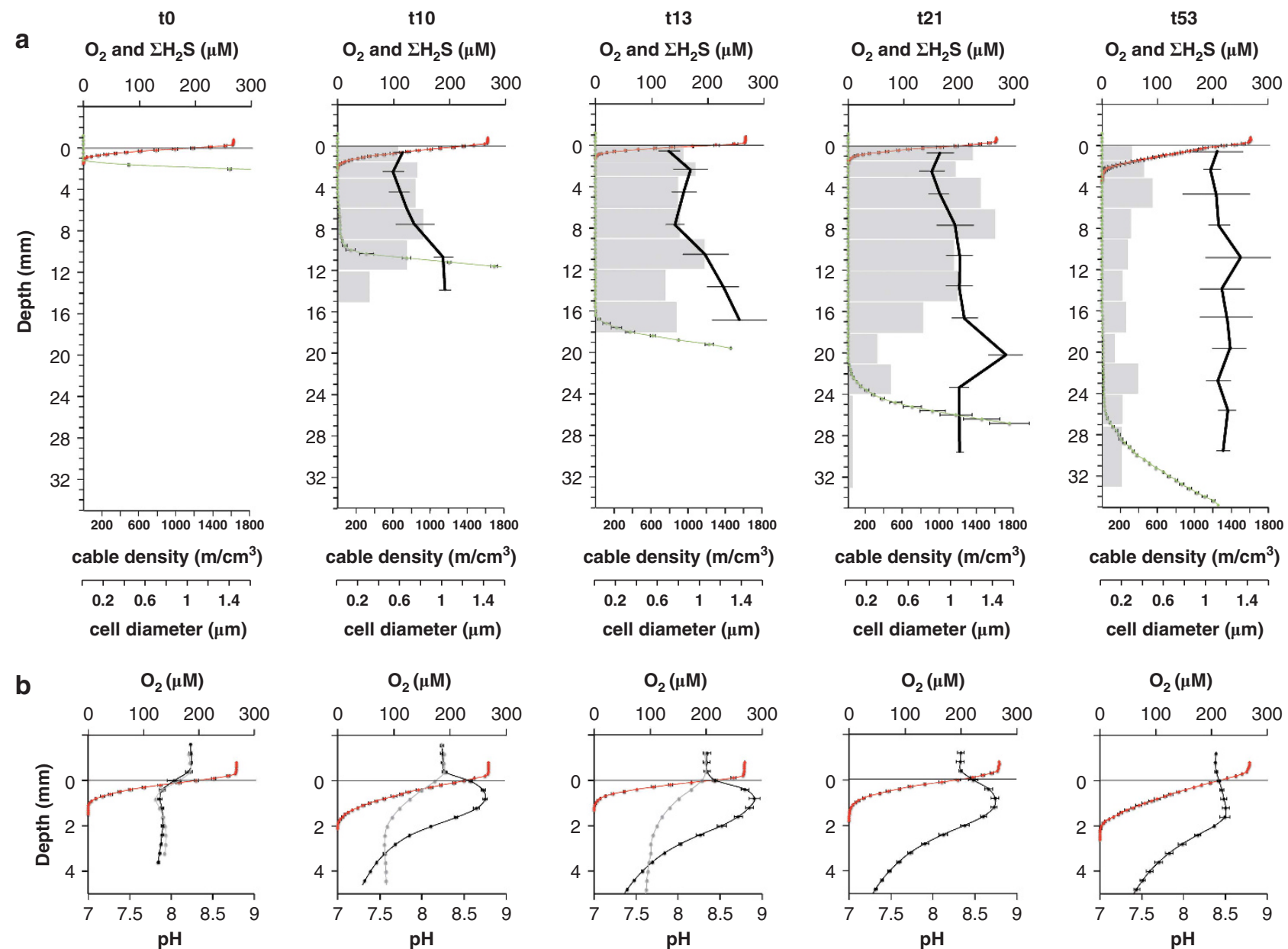

Figure 1 (a) Depth distribution of oxygen (red), sulphide (green), cable bacteria density (grey bars) and cable bacteria diameter (black line) over time during sediment incubations. Time of incubation is given in days (t0-t53). Mean values $( \pm \mathrm{s}$.d.; $n=3)$ are shown for triplicate chemical profiles. Mean values of diameters ( \pm s.d.; $n=3-15$ ) are weighted by the square and on the basis of all analysed cables for each time point and depth. (b) Close-up of the oxic zone with microprofiles of oxygen (red) and pH (black); mean \pm s.d. ( $n=3$ ). In addition, single $\mathrm{pH}$ profiles (grey) are shown for control cores, from which cable bacteria growth was excluded by polycarbonate filters.

current density at day 10 and only $6 \%$ at day 53 , assuming that the end product of sulphide oxidation was $\mathrm{SO}_{4}^{2-}$.

The control cores with a horizontal polycarbonate filter (pore size $0.22 \mu \mathrm{m}$ ) inserted at $2 \mathrm{~mm}$ depth did not show any indications of electric currents as neither $\mathrm{O}_{2}-\sum \mathrm{H}_{2} \mathrm{~S}$ separation, $\mathrm{pH}$ peak nor COC were detected (Supplementary Figure S1, Figure 1b).

Cable bacteria density and morphology

At the beginning of the incubation (day 0) and in the controls at day 0,10 and 13, neither single cells nor filaments were detected by FISH using probe DSB706, which means less than $1.5 \times 10^{6}{\mathrm{cells} \mathrm{cm}^{-3}}^{-3}$ or $10 \mathrm{~cm}$ filaments $\mathrm{cm}^{-3}$ were present. After 10 days, however, cable bacteria reached a density of $1150 \mathrm{~m} \mathrm{~cm}^{-2}$, with filament abundance evenly distributed over the $0-15 \mathrm{~mm}$ depth interval, that is throughout the oxic-suboxic zone (Figure 1a). Assuming that the cable bacteria were arranged as single, straight, continuous filaments spanning the entire suboxic zone, we estimate that $8 \times 10^{4}$ single filaments were present per $\mathrm{cm}^{2}$. This corresponds to an average distance between cable bacteria of $35 \mu \mathrm{m}$. Cable bacteria density peaked after 21 days (Figures 1a and 2) with $2380 \mathrm{~m} \mathrm{~cm}^{-2}$, that is more than $2 \mathrm{~km}$ of cables under each $\mathrm{cm}^{2}$ of sediment. With an average cell length of $3 \mu \mathrm{m}$ (Pfeffer et al., 2012), this density corresponds to $8 \times 10^{8}$ cable bacteria cells $\mathrm{cm}^{-2}$. In comparison to the total cell density at $1.5-3 \mathrm{~mm}$ depth $\left(1.5 \times 10^{9} \mathrm{cells}^{-3}\right)$, the cable bacteria $\left(4 \times 10^{8}\right.$ cells $\left.\mathrm{cm}^{-3}\right)$ accounted for $25 \%$ of the total microbial community. After 53 days, the cable density had decreased to $930 \mathrm{~m} \mathrm{~cm}^{-2}$. Filament abundance always dropped right below the transition to the sulphide zone. The recorded filament widths varied by a factor of 4 $(0.4-1.7 \mu \mathrm{m})$ with prevalence of small widths in the top $10 \mathrm{~mm}$ of the sediment during the first 2 weeks (Figure 1).

At first (days 10 and 13) the average diameter increased with depth from 0.6 to $1.3 \mu \mathrm{m}$, and at the 


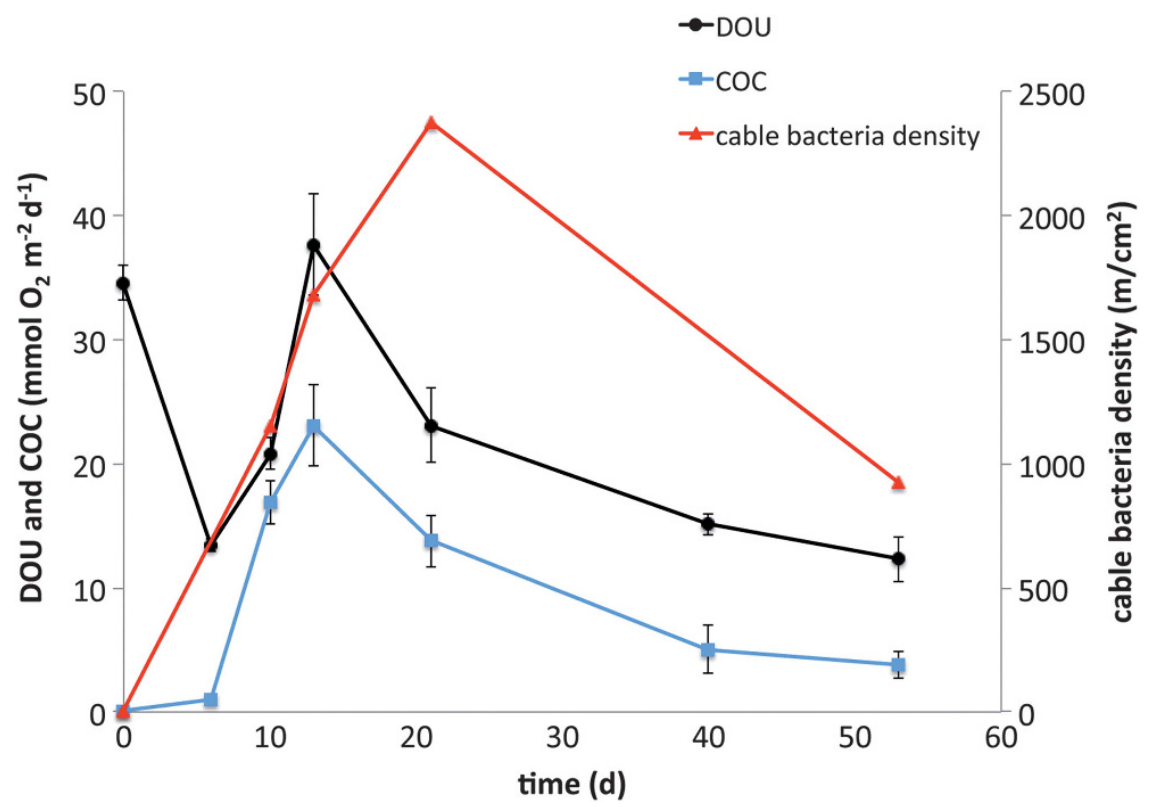

Figure 2 Diffusive $\mathrm{O}_{2}$ uptake (DOU) (black), cathodic oxygen consumption (COC) as mean of triplicate cores (blue) and depth integrated cable bacteria density detected by FISH (red).

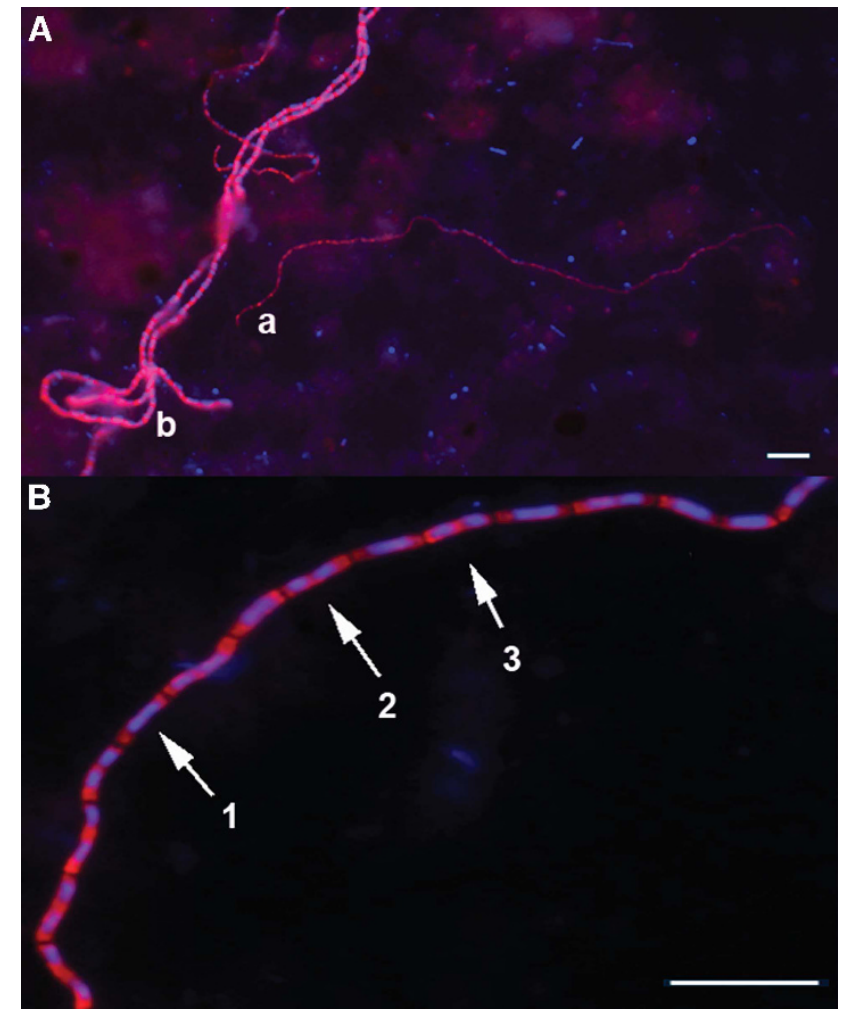

Figure 3 (A) Cable bacteria in incubated marine sediment targeted by the DSB706 probe, showing different phenotypes of cable bacteria with (a) $0.7 \mu \mathrm{m}$ (t21) and (b) $1.2 \mu \mathrm{m}$ (t21) diameters. (B) Different stages of cell division were detected in cells along the multicellular cables (1) daughter chromosomes located side by side, (2) cell division is initiated in the middle, (3) daughter chromosomes are located in the middle of the daughter cells. Scale bars, $10 \mu \mathrm{m}$. end (day 53) the average diameter had increased to $1.2 \mu \mathrm{m}$ with no vertical variation (Figure 1a). Thin cable bacteria (Figure 3Aa) thus dominated the surface layers at the beginning, while wider cable bacteria (Figure 3Ab) dominated at the end of the incubation.

In cable bacteria with cell diameters $>1 \mu \mathrm{m}$, different stages of cell division could be observed in cells along the entire filament (Figure 3B), at all time points and in all sediment layers, except for the suboxic/sulphidic transition zone. Filaments with a diameter $<1 \mu \mathrm{m}$ were too thin to allow reliable recognition of cell division.

Cable bacteria diversity

Several 16S rRNA sequences retrieved in this study affiliated with the genus Desulfobulbus (90-94\% sequence similarity) and formed a monophyletic group with previously published sequences from cable bacteria (Pfeffer et al., 2012), with a shared sequence identity of $>98 \%$ within the group (Figure 4). Published sequences most similar (96\%) to this cable bacteria cluster were from surface sediments of a subtropical mangrove habitat (Liang et al., 2007).

Sequences from 13 single cable bacteria with different diameters $(0.48-1.43 \mu \mathrm{m})$ were $99-100 \%$ identical and sequences obtained from bulk sediment RNA extractions after 10 days (representing the thin cable bacteria) and 53 days (representing the wide cable bacteria) were scattered throughout the cable bacteria cluster, with no apparent grouping with time or depth. These data indicate that the 


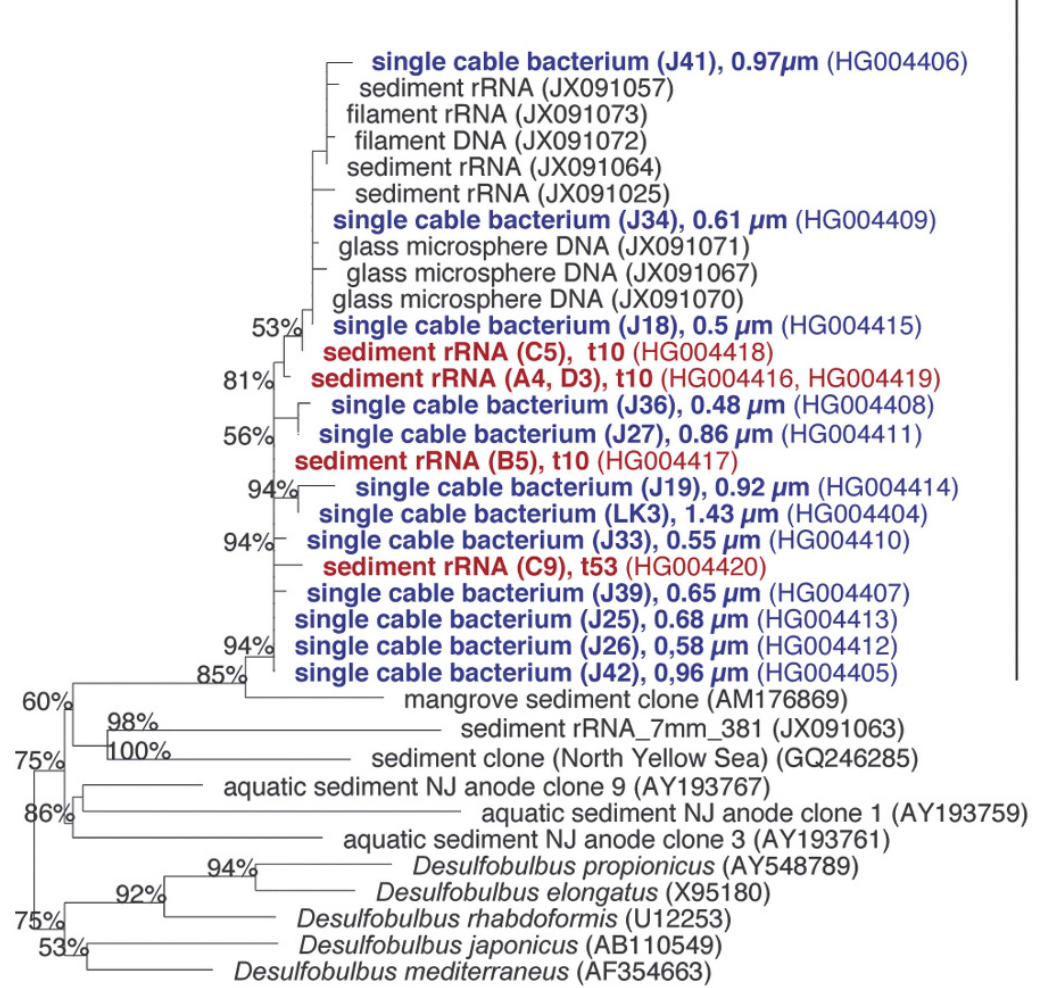

0.10 cable bacteria

cluster

(>98\% identitiy)

Figure 4 Phylogenetic affiliation by maximum-likelihood of 16S rRNA sequences obtained in this study. Bootstrap support (1000 replicates) $>50 \%$ is displayed at the nodes. Sequences obtained from single cable bacteria are shown in blue with their filament diameter indicated, sequences from bulk sediment rRNA are shown in red with the day of sampling indicated. Clone identifier and EMBL accession numbers are given in parentheses. The tree is rooted to Escherichia coli and Vibrio fischeri. The bar represents $10 \%$ estimated sequence difference.

morphologic variation among the cable bacteria is not reflected in phylotypes distinguishable by $16 \mathrm{~S}$ rRNA sequences.

\section{Discussion}

Electric currents and cable bacteria

Profiles of $\mathrm{O}_{2}, \sum \mathrm{H}_{2} \mathrm{~S}$ and $\mathrm{pH}$ developed in the same way as seen in three previous studies of electric currents in sediment, with a distinct $\mathrm{pH}$ peak in the oxic zone and formation of a suboxic zone with no detectable oxygen or sulphide (Nielsen et al., 2010; Pfeffer et al., 2012; Risgaard-Petersen et al., 2012). Over time, the depth distribution of the cable bacteria closely followed the downward expansion of the suboxic zone, suggesting that the cable population developed from the oxygen-sulphide interface near the surface and grew downwards over time. The parallel increase in cable bacteria density and COC during the first 13 days of incubation, and the absence of both in the controls, confirmed that cable bacteria drove the separation of gradients and concurrent change in $\mathrm{pH}$, which are proxies for electrical current. Within 10 days the cable bacteria came to dominate the microbial activity in the sediment as the electric currents accounted for more than $81 \%$ of the sedimentary oxygen uptake (Figure 2). This peak in activity was followed by a peak in abundance after 21 days, by which the cable bacteria had grown from non-detectable at the start to likely being the single most dominating microbial community member, accounting for $25 \%$ of all prokaryotic cells around the oxic/anoxic interface (1.5-3 mm depth).

\section{Growth}

The density of cable bacteria was uniform throughout the oxic and suboxic zones at day 10 (Figure 1a). With growth presumably starting near the oxic zone, this distribution implies that the filaments did not advance in random directions but grew vertically downwards with most of them keeping in touch with both the oxic zone and the retreating front of porewater sulphide. The mode and minimum rate of growth was evaluated from the depth distribution at day 10 when some filaments must have grown to a minimum length of $15 \mathrm{~mm}$ (Figure 1a). As neither single cells nor filaments were detected at day 
0, growth must have started from single cells present in low abundance in the marine sediment. Assuming that each of the filaments present at day 10 started growing from a single cell, the starting population number in a $1.5-\mathrm{mm}$ deep zone would be $5.3 \times 10^{5} \mathrm{~cm}^{-3}$, which lies between the FISH detection limits for filaments $\left(1 \times 10^{4}\right.$ filaments $\left.\mathrm{cm}^{-3}\right)$ and single cells $\left(1.5 \times 10^{6}\right.$ cells $\left.\mathrm{cm}^{-3}\right)$. Proliferation of a single, 3- $\mu \mathrm{m}$-long cell (Pfeffer et al., 2012) into a $15 \mathrm{~mm}$-long filament within 10 days is not feasible by apical growth, as known from filamentous Actinobacteria (Flardh and Buttner, 2009), as it would imply division of the leading cell every $6 \mathrm{~min}$. This is faster than the fastest bacterial growth recorded in cultures (doubling time $10 \mathrm{~min}$; Eagon, 1962). If, on the other hand, the multicellular filaments grew exponentially with continuous and uniformly frequent division of all cells, then the observed growth would require a doubling time of $20 \mathrm{~h}$. This is realistic and microscopic observations indeed showed cell division in multiple cells along the length of the multicellular cable bacteria (Figure 3B). The uniform distribution of cell division and the downwards expansion imply that the filaments by some yet unknown mechanism moved the growing number of cells downwards.

Diffusion of $\sum \mathrm{H}_{2} \mathrm{~S}$ from below did not supply all of the electrons transferred to oxygen, and the additional electron donor source was probably sulphide from dissolution of $\mathrm{FeS}$ and oxidation of sulphide produced from sulphate reduction within the suboxic zone (Mussmann et al., 2003; RisgaardPetersen et al., 2012), besides possibly organic electron donors. This means that most probably all cells in the filaments in the anoxic zone were performing sulphide oxidation and were not merely serving as electron conductors. The availability of sulphide throughout the suboxic zone also implied that not all cable bacteria needed to grow as fast as the expanding suboxic zone. Indeed, at day 21 , the depth distribution of the cable bacteria had become more uneven, indicating that only a fraction of all cables reached down to the free sulphide front at $24 \mathrm{~mm} \mathrm{depth}$, and/or that a part of the cables was no longer arranged as vertical filaments but was curled up in certain layers (Figure 1a).

The cable bacteria are assumed to be mixotrophs as the close balance between sulphide oxidation and oxygen reduction does not leave electrons for $\mathrm{CO}_{2}$ fixation (Risgaard-Petersen et al., 2012). Comparison of biomass accumulation rates with electric current densities allowed estimations of the growth efficiency of cable bacteria. Biovolume was calculated from diameters and length of the FISH detected cable bacteria and converted to dry weight by assuming a cell length of $3 \mu \mathrm{m}$ and using the empirical equation of Loferer-Krossbacher et al. (1998) $\left(\right.$ dry weight $\left.=435 \times \mathrm{V}^{(0.86)}\right)$. For conversion to carbon $50 \%$ of the dry weight was assumed to represent carbon content. From day 10 to day 13 the estimated biomass accruement was $26 \mathrm{mmol} \mathrm{Cm}^{-2}$ per day, which exceeded the concurrent average COC of $20 \mathrm{mmol} \mathrm{O}_{2} \mathrm{~m}^{-2}$ per day. This growth efficiency is exceptionally high compared with other mixotrophs (Pronk et al., 1990; Muntyan et al., 2005; Geelhoed et al., 2010). High growth efficiency implies that electron transport by periplasmic conductive strings, running between cells millimetres apart, did not impose significant energy dissipation or low metabolic efficiency in comparison with conventional cellular electron transport. More detailed rate measurements and determination of carbon/volume ratios in cable bacteria are warranted to verify the intriguing high metabolic efficiency indicated so far.

Cell-specific respiration rates of the oxygen-reducing cable cells in the oxic zone with a maximum of $36 \mathrm{fmol} \mathrm{O}_{2}$ per cell per day on day 10 were high compared with aerobic sulphide oxidizers (for example, Thiobacillus thiooxidans, $2.5 \mathrm{fmol}_{2}$ per cell per day) or the most closely related sulphate reducers (Desulfobulbus propionicus, $9 \mathrm{fmol} \mathrm{O}_{2}$ per cell per day (Makarieva et al., 2005). Less than 10\% of the cable bacteria cells were situated in the oxic zone and therefore the average cell-specific electron turnover for the sulphide-oxidizing cells was at least 9 times lower than for the oxygen-reducing cells; that is, more comparable to the other sulphide oxidizers. Growth occurred at all depths, and if the high growth efficiency estimated above holds true, almost all the energy from the aerobic sulphide oxidation must have been used in the suboxic zone by the sulphide-oxidizing cells for growth. This would imply that the electric potential on the electron conductors stayed close to the redox potential of oxygen.

\section{Variations in filament thickness}

Intriguingly the recorded filament widths varied by a factor of $4(0.4-1.7 \mu \mathrm{m})$ and the average diameter increased with depth and time of cable growth (Figure 1a). At the phylogenetic resolution of $16 \mathrm{~S}$ rRNA sequences the different diameters were not found to represent different phylotypes (Figure 4). All retrieved sequences related to the cable bacteria cluster shared a sequence identity $>98 \%$ and formed a monophyletic group with previously published sequences from cable bacteria (Pfeffer et al., 2012). A more detailed study is required to determine whether the size variability was due to different populations, developmental stages or physiological conditions.

\section{Life of cable bacteria}

After our first observations of cable bacteria at day 10, documenting a rapid growth rate with a doubling time $<20 \mathrm{~h}$, it took another 10 days to achieve a further net doubling of the biomass (Figure 2), indicating that the net rate of biomass accrual declined. Between days 21 and 53, the density and activity of the cable bacteria dropped by more than 
$50 \%$ (Figure 2). Depletion of the FeS pool in the suboxic zone is here proposed as the most likely reason for the decline. In this study $\mathrm{FeS}$ was not analysed directly, but the colour of the suboxic zone changed from black to grey towards the end of the incubation, presumably as FeS disappeared. Previous incubation experiments confirmed a depletion of the reduced iron pool in the suboxic zone after 72 days of incubation (Risgaard-Petersen et al., 2012). Declining cell-specific activity, as expected upon substrate depletion, was evident from a threefold drop in the ratio between COC and cable density from day 10 to day 53 (Figure 2). It is an intriguing question why the requirement for sulphide did not result in further expansion of the suboxic zone beyond a depth interval of $20 \mathrm{~mm}$ (Figure 1a). Also in previous studies, the suboxic zone did not exceed 12-19 mm, even after 21-45 days of incubation, despite large variations in COC and different sediment sources (Nielsen et al., 2010; Pfeffer et al., 2012; Risgaard-Petersen et al., 2012). Does the mode of electron transport in cable bacteria impose some general restrictions on the active length? Are these limitations due to the physics of cellular electron transport?

The sediment incubations simulated a situation in the environment where sulphidic sediment formed in a period of bottom water oxygen depletion becomes re-exposed to oxygen. In situ porewater profiling in Tokyo Bay has indeed found the signatures of electric currents under such a situation (Sayama, 2011). While the present study reported a bloom of cable bacteria apparently depleting the sediment pool of $\mathrm{FeS}$ and then disappearing, it remains to be demonstrated whether the same scenario happens in nature or more persistent cable bacteria communities relying on continuous electron donor sources exist in the sea bottom.

In summary this study showed how cable bacteria, within a short period of time, monopolized both sulphide oxidation and oxygen consumption in marine sediment newly exposed to oxygen. The cable bacteria combined electron conductance with rapid, efficient and oriented growth as multicellular filaments of variable width. These remarkable competences open many more intriguing questions, regarding the underlying physical, physiological and genetic mechanisms.

\section{Conflict of Interest}

The authors declare no conflict of interest.

\section{Acknowledgements}

We thank the captain, Torben Vang, of the vessel Thyra, as well as Christian Pfeffer and Lorenz Lagostina for their help during sampling at sea and PG Sørensen for construction of microsensors. The research leading to these results has received funding from the European Research Council under the European Union's Seventh
Framework Programme (FP/2007-2013)/ERC Grant Agreement no 294200 (BBJ) and 291650 (LPN). Furthermore, this research was financially supported by the Danish National Research Foundation DNRF104 (NR-P, KUK, $\mathrm{BBJ}$ ), the Danish Council for Independent Research I Natural Sciences (FNU) (LPN) and the German Max Planck Society (RS, NR-P, KUK, BBJ).

\section{References}

Berg P, Risgaard-Petersen N, Rysgaard S. (1998). Interpretation of measured concentration profiles in sediment pore water. Limnol Oceanogr 43: 1500-1510.

Boudreau BP. (1996). Diagenetic models and their implementation: modelling transport and reactions in aquatic sediments. Springer: New York.

Eagon RG. (1962). Pseudomonas natriegens, a marine bacterium with a generation time of less than $10 \mathrm{~min}$. J Bacteriol 83: 736-737.

Flardh K, Buttner MJ. (2009). Streptomyces morphogenetics: dissecting differentiation in a filamentous bacterium. Nat Rev Microbiol 7: 36-49.

Geelhoed JS, Kleerebezem R, Sorokin DY, Stams AJM, van Loosdrecht MCM. (2010). Reduced inorganic sulfur oxidation supports autotrophic and mixotrophic growth of Magnetospirillum strain J10 and Magnetospirillum gryphiswaldense. Environ Microbiol 12: 1031-1040.

Jeroschewski P, Steuckart C, Kuhl M. (1996). An amperometric microsensor for the determination of $\mathrm{H}_{2} \mathrm{~S}$ in aquatic environments. Anal Chem 68: 4351-4357.

Kjeldsen KU, Loy A, Jakobsen TF, Thomsen TR, Wagner M, Ingvorsen K. (2007). Diversity of sulfate-reducing bacteria from an extreme hypersaline sediment, Great Salt Lake (Utah). FEMS Microbiol Ecol 60: 287-298.

Lane DJ. (1991). 16S/23S rRNA sequencing. In: Stackebrandt E, Goodfellow M (eds). Nucleic Acid Techniques in Bacterial Systematics. Wiley: Chichester, pp 115-175.

Liang J-B, Chen Y-Q, Lan C-Y, Tam NFY, Zan Q-J, Huang L-N. (2007). Recovery of novel bacterial diversity from mangrove sediment. Mar Biol 150: 739-747.

Loferer-Krossbacher M, Klima J, Psenner R. (1998). Determination of bacterial cell dry mass by transmission electron microscopy and densitometric image analysis. Appl Environ Microb 64: 688-694.

Ludwig W, Strunk O, Westram R, Richter L, Meier H, Yadhukumar et al. (2004). ARB: a software environment for sequence data. Nucleic Acids Res 32: 1363-1371.

Makarieva AM, Gorshkov VG, Li BL. (2005). Energetics of the smallest: do bacteria breathe at the same rate as whales? Proc Biol Sci 272: 2219-2224.

Manz W, Amann R, Ludwig W, Wagner M, Schleifer KH. (1992). Phylogenetic oligodeoxynucleotide probes for the major subclasses of proteobacteria: problems and solutions. Syst Appl Microbiol 15: 593-600.

Muntyan MS, Grabovich MY, Patritskaya VY, Dubinina GA. (2005). Regulation of metabolic and electron transport pathways in the freshwater bacterium Beggiatoa leptomitiformis D-402. Microbiology 74: 388-394. 
Mussmann M, Schulz HN, Strotmann B, Kjaer T, Nielsen LP, Rossello-Mora RA et al. (2003). Phylogeny and distribution of nitrate-storing Beggiatoa spp. in coastal marine sediments. Environ Microbiol 5: 523-533.

Muyzer G, Dewaal EC, Uitterlinden AG. (1993). Profiling of complex microbial populations by denaturing gradient gel-electrophoresis analysis of polymerase chain reaction-amplified genes-coding for $16 \mathrm{~S}$ ribosomal RNA. Appl Environ Microbiol 59: 695-700.

Nielsen LP, Risgaard-Petersen N, Fossing H, Christensen PB, Sayama M. (2010). Electric currents couple spatially separated biogeochemical processes in marine sediment. Nature 463: 1071-1074.

Pernthaler J, Glockner FO, Schonhuber W, Amann R. (2001). Fluorescence in situ hybridization (FISH) with rRNA-targeted oligonucleotide probes. Method Microbiol 30: $207-226$.

Pfeffer C, Larsen S, Song J, Dong M, Besenbacher F, Meyer RL et al. (2012). Filamentous bacteria transport electrons over centimetre distances. Nature 491: 218-221.

Pronk JT, Meulenberg R, Vandenberg DJC, Batenburgvandervegte W, Bos P, Kuenen JG. (1990). Mixotrophic and autotrophic growth of Thiobacillus acidophilus on glucose and thiosulfate. Appl Environ Microbiol 56: 3395-3401.

Pruesse E, Quast C, Knittel K, Fuchs BM, Ludwig WG, Peplies J et al. (2007). SILVA: a comprehensive online resource for quality checked and aligned ribosomal RNA sequence data compatible with ARB. Nucleic Acids Res 35: 7188-7196.
Pruesse E, Peplies J, Gloeckner FO. (2012). SINA: Accurate high-throughput multiple sequence alignment of ribosomal RNA genes. Bioinformatics 28: 1823-1829.

Revsbech NP, Jorgensen BB. (1986). Microelectrodes-their use in microbial ecology. Adv Microb Ecol 9: 293-352.

Revsbech NP. (1989). An oxygen microsensor with a guard cathode. Limnol Oceanogr 34: 474-478.

Risgaard-Petersen N, Revil A, Meister P, Nielsen LP. (2012). Sulfur, iron-, and calcium cycling associated with natural electric currents running through marine sediment. Geochim Cosmochim Acta 92: 1-13.

Sayama M. (2011). Seasonal dynamics of sulfide oxidation processes in Tokyo Bay dead zone sediment. Goldschmidt 2011-Earth, Life and fire. Prague: Czech Republic.

Sayre JD. (1926). Physiology of Stomata of Rumex Patientia. Ohio J Sci 26: 233-266.

Soetaert K, Hofmann AF, Middelburg JJ, Meysman FJR, Greenwood J. (2007). The effect of biogeochemical processes on $\mathrm{pH}$ (Reprinted from Marine Chemistry, vol 105, pg 30-51, 2007). Mar Chem 106: 380-401.

Stumm W, Morgan JJ. (1981). Aquatic Chemistry, 2nd edn. John Wiley \& Sons Inc.: New York, pp 179-206.

Teske A, Wawer C, Muyzer G, Ramsing NB. (1996). Distribution of sulfate-reducing bacteria in a stratified fjord (Mariager fjord, Denmark) as evaluated by most-probable-number counts and denaturing gradient gel electrophoresis of PCR-amplified ribosomal DNA fragments. Appl Environ Microbiol 62: 1405-1415.

Ullman WJ, Aller RC. (1982). Diffusion-coefficients in nearshore marine-sediments. Limnol Oceanogr 27: 552-556.

Supplementary Information accompanies this paper on The ISME Journal website (http://www.nature.com/ismej) 